研究発表論文

\title{
日独の森林イメージに関する比較研究
}

\section{A Comparative Study on Forest Image in Japan and Germany}

\author{
上田 裕文* \\ Hirofumi UEDA
}

\begin{abstract}
This study aimed to compare forest image molded by individual experience and culture. Students in Japan and Germany answered questionnaire and made drawings of their forest image, and the elements composing the forest image differed. Japanese students tended to draw a motive of their own impressive experiences, while German students described the forest more objectively. The drawings were categorized in three types, namely "Object", "Natural landscape", and "Cultural landscape" according to the representation of civilization and the relationship to the individuals. The majority of the drawings of the German students were categorized in "Object". They often have stable rich experience in visiting forests. The drawings of the Japanese students differed depending on their experience during childhood and rare actual visits.
\end{abstract}

Keywords: Germany, Japan, Forest, image, drawing, questionnaire キーワード：ドイッ，日本，森林，イメージ，描画，アンケート

\section{1.はじめに}

景観研究が様々な角度から行われる中で, 上田 ${ }^{1)}$ は前稿におい て知覚・認知・記憶を経て心理的空間に変換された個人の森林イ メージが, 幼少期の環境・森林体験・知識といった森林との関わ り方に関する，個人背景に影響を受けながら形成されていること を指摘した。しかし, 個人で異なる森林イメージにも, より大き な文化的枠組みといった視点から見れば，その根底にある程度類 似した傾向を見いだせる可能性がある。本稿では, 森林イメージ の文化的枠組みを浮き彫りにするため, 森林との関わりが深く, 日本が林業技術に関しても多くの影響を受けているドイツを対象 に，個人の持つ森林イメージとその形成過程の比較を試みる。

森林観の国際比較に関しては, 四手井ら ${ }^{2)}$ や比屋根ら ${ }^{3)}$ の研究 があるが，それらは一般的な森林観の違いを個人の意識や態度か ら明らかにしているものの, それらを形成する要因にまで考察が 及んでいない。また，北村 ${ }^{4)}$ は日独の自然観について，ドイッの 「理念的」な理解と日本の「観念的」な理解の相違を指摘してい るが, Braun ${ }^{5)}$ はドイツ人にとっての「森」の意味は世代ととも に変化し, かつての合理的世代から情緒的世代への変化とともに 森林の理解も多様化していると述べており, Schriewer ${ }^{6)}$ む若い 世代の森林観は手つかずの自然を理想化する傾向にあると指摘し ていることからも, 現在ではドイッの森林観も日本とあまり差が 無い事が予想される。また, 森林観の形成過程や要因に関して Lehmann $^{7)}$ は，森林観は幼少期から青年期までに形成され，そ の要因は知識のみならず美的な好みによるとし, 大越ら ${ }^{8)}$ も森林 体験が子供の森林イメージに与える影響を明らかにしている。こ れらをふまえ, 本研究では, 若い世代にとっての森林イメージを, 言葉による概念的理解だけでなく, 景観としての総合的な捉え方 から日独で比較することで，その文化的な違いを明らかにし，さ らにその形成要因として, 幼少期の環境・森林体験・知識といっ た森林との関わり方を対応させることで考察を深めるのが目的で ある。

\section{2. 研究方法}

\section{（1）調査地之対象}

調査ではドイッのほぼ中央に位置する，ヘッセン州の主要都市 カッセル市のカッセル大学の学生と日本の東京大学の学生を対象 とした。四手井らは当時,「西ドイツと日本の住民意識の間にあ る超え難い程大きな相違に比べれば，国内の諸都市の間の相違は 遥かに小さいと言わねばならない」と述べており,「西ドイッの 諸都市に至っては, 同一都市のデー夕と見まごう程酷似して」お り，また東京都に関しても「他都市との本質的な相違はない」9 と述べているため, 日独比較の対象地として両都市を選ぶことは 妥当であると判断した。また調査は, 景観に関心を持ち, かつ専 門分野をまだ深く学んでいない学生を対象とするため, まず 2004 年にカッセル大学の建築・都市計画・景観計画学部で,「都 市の美観」と「空間と行動－公共の空間」の講義を受講する学生 を対象に実施し，続いて同じ質問紙を和訳し，2005 年に東京大 学の教養課程の 2 年生で農学部への進学が内定しており,「環境 と景観の生物学」を受講する学生を対象に実施した。（以下，ド イツの回答者, 日本の回答者之表記)。その際, 両国の森林イメー ジの文化的枠組みを比較するため，それぞれの国の滞在年数が短 い留学生は分析の対象から外し, ドイッの回答者 45 人, 日本の 回答者 62 人のデー夕を分析対象とした。回答者の最年少はドイ ツの回答者で 18 歳, 日本の回答者で 19 歳で, 平均年齢はそれぞ れ 23.2 歳と 20.6 歳であった。

\section{(2) 調査方法}

調査は, 講義の時間中に質問紙を配布し実施した。主な質問項 目は「幼少期の環境」（選択式）「幼少期の遊び場」（記述式）「森 林体験頻度」（記述式）「知っている樹種数」（選択式）である。 それに加えて,「森林」と聞いて思い描く景観 1 シーン（以下, 「森林イメージ」と表記）を描画してもらい，その構成要素や状 況の説明を簡単な文章にしてもらった。

\footnotetext{
*カッセル大学建築・都市計画・景観計画
} 


\section{3．日独の回答者の個人属性}

まずは両国の回答者の個人属性を概観する。森林に関する知識 の大まかな目安となると考えられる「知っている樹種数」を選択 式で回答してもらい得点化した（1：～5 種類, $2 ： 6 \sim 10$ 種 類, $3: 11 \sim 20$ 種類, $4: 21 \sim 30$ 種類, $5: 31$ 種類〜)。両国 の基本的な植生の違いを考えると単純に比較する事はできないが, その結果は図－1のようになり, 分布は似ているが平均得点が 2.5 点と 2.8 点で日本の回答者の方が若干少ない事が分かる。

また，「幼少期の環境」で周りにあった「みどり」を選択式で 回答してもらったところ (図-2), ドイツの回答者では「森」 87\%「農地」84\%「草原」76\%の回答率がそれぞれ高かったのに 対し, 日本では「森」36\%「農地」42\%「草原」 $18 \%$ と低く, 実 際の国土利用とは異なる，日独の原風景が見えてくる。一方で日 本の回答者では「公園」の回答率が $92 \%$ と圧倒的に高く, ドイ ツの回答者での「公園」の回答率は $18 \%$ であた。

次に「幼少期の遊び場」を記述式で尋ねたところ, 回答に同様 の傾向が見られ (図-3), ドイッの回答者では「森」が $36 \%$ 之 最も回答率が高く，次が「庭」(33\%) で「公園」(25\%)「草原」 (24\%)「道,駐車場」（22\%）「川,池」（16\%）「農地」（11\%）と 続く。一方日本の回答者では「公園」(58\%)「学校」(19\%)「道, 駐車場」（13\%）の回答率が比較的高く，屋内である「家」も 10 \%で回答された。ドイッでは放課後に校庭が開放されない事や, 各家庭に庭が多い事が表れた結果だが，ここでも森林との関わり 方の違いが顕著に表れていると言える。

さらに，「森林体験頻度」を成長の各段階で見るため，ドイッ の Grundschule（ 4 年間), Gymnasium（ 9 年間), 大学入学後 之, 日本ではそれにほぼ対応する小学校時代, 中学・高校時代, 大学入学後の各時期で森を訪れた頻度を記述式で尋ねた。個人の バラツキが大きく, 週に 1 回や月に 2 ・ 3 回といった曖昧な表現 屯見られたため, 分析の際には 1 年あたりの回数に換算し得点化 した（0：0回, 1：1〜3 回, 2:4 10 回, 3:11 30 回, $4: 31 \sim 60$ 回, $5: 61$ 回〜)。平均值を図-4に示すと, ドイツ の回答者が圧倒的に森を訪れる頻度が高い事が分かる。しかし， これらの質問は, いずれも回答者にとっての「森」に関して尋ね たものであり, ここでの課題は, 各回答者がどのように「森」を 定義しているかという事になる。ドイツの回答者にとって森林が 身近な環境として存在している事は, 各データに一貫して表れて いるが，一方で森林が身近に存在しない多くの日本の回答者にとっ て，森林体験は非日常的なものにならざるを得ない。そこで，日 本の回答者に対しては,「森林体験頻度」に加えてのその主な内 容も記述してもらった。年に 1 ・ 2 回と答える回答者はその内容 が主に「遠足」「登山」「キャンプ」などの課外学習活動となり, その他に「家族旅行」などとなるのに対して, 森を多く訪れたと いう回答の中には,「遊ぶ」と共に「学校の裏山」「近くの雑木林」 「公園の森」「神社の森」という記述も見られ, 同じ「森」であっ てそのイメージは実に多様である事が分かる。以下, 日独の回答 者の「森林イメージ」を描画および文章記述から見ていく。

\section{4. 日独の回答者の「森林イメージ」の特徵}

前稿において「森林イメージ」は, 森林を捉える際の視点と距 離感, 道や人工物が加わる事によって表現される, 人間の自然へ の介入の度合いから類型化され, さらに実際の森林景観の認識過 程においても, 対象, 対象場, 視点場といった, 異なる森林と主 体との関係性によって森林が捉えられている事が推察された。本 稿ではこの知見を活かして,（1）まず「森林イメージ」を概観 するために, 描画および文章記述に見られる構成要素を項目ごと に集計して検討し，（2）次に描画内容から，「森林イメージ」を 人間の自然への介入の度合いと, 視点と距離感から分類し, 文章
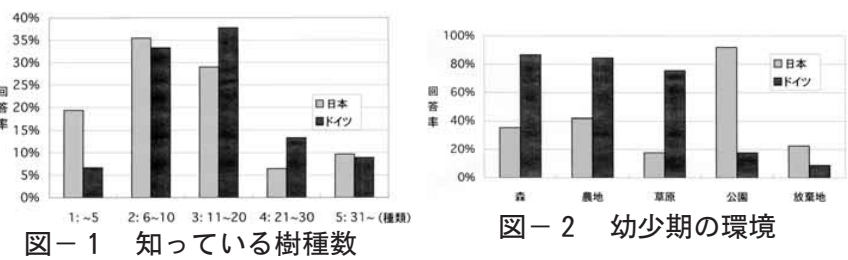

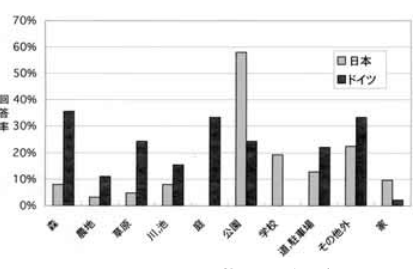

図-3 幼少期の遊び場

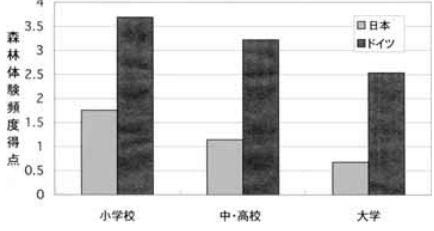

図-4 森林体験頻度

記述内容と合わせてタイプごとに特徵づけを行う。（3）最後に, タイプごとに個人属性を対応させて, 森林との関わり方と「森林 イメージ」の関係から日独の森林イメージを考察する。

\section{(1)「森林イメージ」の構成要素}

両国の「森林イメージ」を概観するため, 個人の描画能力の差 を考慮して, 描かれた構成要素と文章に記述された構成要素とを 合わせて「樹木」, 花や下草, 落ち葉といった「林床」「道」, 動 物や昆虫などの「生き物」, 川や池，湖などの「水」「山，眺望」 標識や柵, 家や車といった「人工物」「人」「行動」, 鳥の鳴き声 や葉ずれの音, 静けさといった「音」, 木漏れ日や暗さなどの 「光」「新鮮な空気」「温度」の項目で整理し, 記載率を日独の回 答者間で比較した（図一 5 , 表一 1 )。「樹木」に関しては基本的 にほぼ全ての回答者で描かれていたが，一部例外として，遠景の 山や，面的な土地利用区分として樹木が描かれないこともあった。 描かれた樹木の形態から判断される林相は, ドイツの回答者では $56 \%$ が意識的に針葉樹と広葉樹を描き分けた針広混交林であり， 広葉樹林，針葉樹林と続く。それに対して日本の回答者では 60 \%が広葉樹林であり, 次に針葉樹林, 針広混交林と続いた。また, ドイツの回答者にのみ一部倒木が描かれた。「林床」「道」「生き 物」はドイツの回答者に記載率が高く, ドイッの道は遊歩道に限 られるのに対し，日本では車道も描かれた。それに対し「水」 「山, 眺望」「人工物」に関しては日本の回答者の記載率が高かっ た。また「人」が描かれるのは日本の回答者のみに見られる特徵 である。描画に表れない森林の特徴としては,「音」に関しては ドイツの回答者の記載率が高く, 日本の回答者が主に「鳥・動物 の声」「川のせせらぎ」を挙げるのに対し, ドイツの回答者では「静か」という記述が 圧倒的に多く，一部「葉ずれの音」などが 挙げられた。「光」に関しては両国で「木

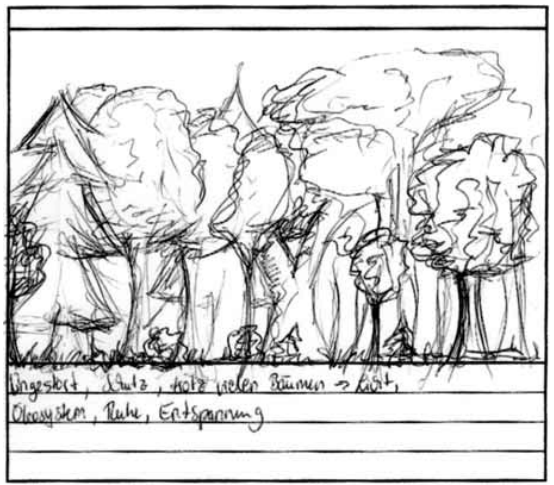

図ー 5 「森林イメージ」例

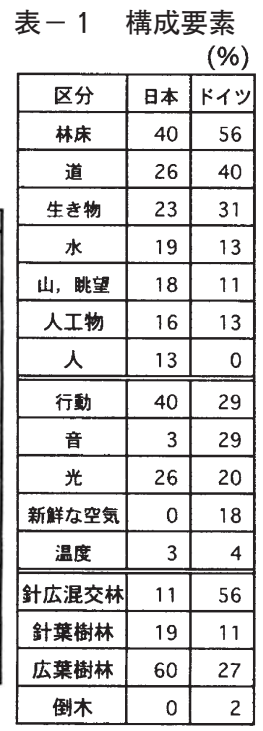


漏れ日」と「暗い」が同じ頻度で記述され,「新鮮な空気」の記 述はドイッの回答者のみに記述された。「行動」に関しては，ド イツの回答者ではほとんどが「保養」「散歩」で, それ以外に林 業に関する「手入れ」または「保全」が記述され, 日本の回答者 では主に個人的な体験の記憶が記述されているようで回答にバラ ツキが見られる。その中で複数記述されたのは「登山」「眺める」 「迷う」「遊ぶ」「ドングリ拾い」で，林業に関する「手入れ」な じも見られた。また両国で, 空想の森も描かれており, ドイッで は「魔女の森」が，日本では「アマゾンの熱帯雨林」「ドイツの シュバルツバルト」「北欧の森」といった外国の森林が想起され ていた。

\section{(2)「森林イメージ」の分類}

ヨーロッパの自然は人間によって飼いならされた自然であると 言われるが, 日独の森林と人間との関係性は, 描画された「森林 イメージ」から読み取れるのであろうか。ここでは描画内容を分 類する 3 つのカテゴリーとして「対象」「自然景観」「文化景観」 を用いた。「対象」は樹木に加えて植物などの「林床」などから 構成された森林そのもので,「自然景観」は「水」や「山,眺望」 など他の自然地理的な要素と組み合わせられる事で，1 つの風景 が構成された森林, 「文化景観」は「道」や「家」などの「人工 物」, 主体自身である「人」が描かれる事によって, 主体との連 続性が示され，人間の自然への介入が進んだ森林である。この3 つのカテゴリーを，樹木の描き方によって表現された視点の取り 方と森林との距離感からさらに細かく「近景」「中景」「俯瞰景」 「遠景」に分け，合計 12 タイプに分類した（表一 2 )。

「対象」として描かれた「森林イメージ」は両国において最も 多く想起され, 特にドイツの回答者では半分以上を占め, そのほ とんどが横からの視点で描かれた「対象・中景」である。一方日 本の回答者では「近景」から「遠景」までその視点と距離が多様 である。「自然景観」として描かれた「森林イメージ」は日本の 回答者に特徵的で, 特に上からの視点で描かれた「自然景観・俯 瞰景」となる傾向がある。「文化景観」として描かれた「森林イ メージ」は両国で想起され, 横からの視点で描かれた「文化景観・ 中景」と, 上からの視点で描かれた「文化景観・俯瞰景」とが主 である。以下，10\%以上で想起された，日本の回答者で 6 タイプ, ドイツの回答者で 4 タイプの「森林イメージ」に関して文章記述 内容と合わせてカテゴリーごとに詳しく見ていく（表－3）。

(i )「対象」としての「森林イメージ」

森林のみを客観的に描写した「対象」としての「森林イメージ」 は，両国で最も多く描かれており，描写する森林の範囲により 「近景」「中景」と「俯瞰景」とに分かれる。主体の視点から描か れた「森林イメージ」は, ドイツの回答者ではほぼ画一的に「対 象・中景」として描かれるのに対し, 日本の回答者では一部が, さらに森林に接近し, 樹幹のみを描いた「対象・近景」として表 現され,「林床」などを含めた詳細な林内景観の描写とともに 「見上げる」という行為と「木漏れ日」が表現される傾向がある。 「木漏れ日」に関する記述はドイツの回答者における「対象・中 景」にも見られ，その際には「保養」といった行為と結びつく。 また，針広混交林が多く描かれる点も両夕イプで共通しているが， 林内景観を詳しく観察し,「光」「音」「温度」の記述とともに客 観的に描写している点で, 主に広葉樹林として描かれている日本 の回答者の「対象・中景」とも類似点が見られる。これらの中に は「道」や「散歩」「登山」といった「行動」に関する記述から, 林道脇の景色を描写したと思われるものや，林業に関する「手入 れ」「植物遷移」に言及したものも見られる。広い範囲の森林を より概念的に表現した「対象・俯瞰景」では, ドイッの回答者で 「林床」や「生き物」に関する表現が増加し,「倒木」などとも結 びついて「エコシステム」や「生物多様性」などが広葉樹林また
表一 2 「森林イメージ」の分析

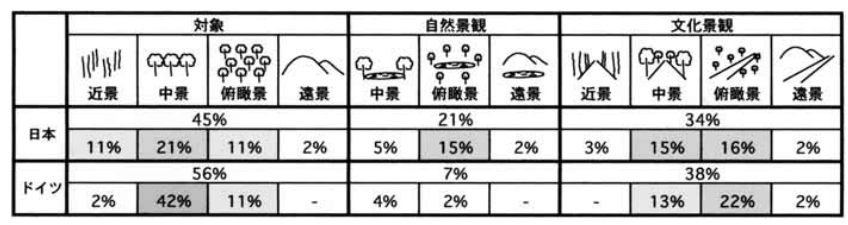

は針広混交林として描かれるのに対し，日本の回答者では，「見 学」や「迷う」などの「行動」に関する記述が，密で暗い針葉樹 林の描写とともに増加し,「森林イメージ」がより非日常的な体 験の記憶として想起されている事が分かる。

(ii )「自然景観」としての森林

森林以外の自然地理的な要素と組み合わされて「自然景観」と して描かれる「森林イメージ」は，日本の回答者に特徵的である。 主に上からの視点で「水」や「山, 眺望」と組み合わされて描か れた「自然景観・俯瞰景」は, 美しい風景のモデルとして表現さ れている傾向がある。そのため「眺める」という行為と結びつい て, 実際に山の上から森林を見下ろした「森林イメージ」以外は, 「行動」に関する記述がほとんど見られず，「調和」という記述に 見られるように, 静的な美しい自然風景が表現されているものと, ドイツの回答者の「対象・俯瞰景」に類似する概念的な生態系が 表現されているものとに分かれる。

(iii）「文化景観」としての「森林イメージ」

「道」や家などの「人工物」さらには「人」と組み合わされ， 主体との連続性や，人間の自然への介入が進んだ森林が両国で 「文化景観」として描かれるが，日本の回答者の中には「お寺」 や「神社」の森,「ブロック塀」に囲まれた敷地の森といった, 幼少期に慣れ親しんだ森や，さらには「街路樹」を描いたものが 含まれ, 森林の定義に幅がある事が見て取れる。「文化景観・中 景」では両国に共通して, 主に遠近表現で中央に「道」が描かれ, 「遊歩道」や「実家」「家の裏」という記述と結びついた，身近な 森林が想起されている。しかし，日本の回答者では「行動」に関 する記述が全体の中で最も多いのに対し，ドイツの回答者では逆 に最も少なく，体験の場として想起している日本の回答者と，居 住地の周辺にある空間として想起しているドイッの回答者の間に 違いが見られる。両国でより概念的な「文化景観・俯瞰景」では, 日本の回答者で, 幼少期に遊んだ人工的な森や「登山」と結びつ いた体験の記憶, 海外の森林のイメージに分けられるのに対し, ドイッの回答者では「池」や「小川」などの「水」や「理想の」 という記述と結びついて, 日本の回答者での「自然景観・俯瞰景」 に類似する自然風景が描かれたものと，ドイツの回答者の「対象・ 俯瞰景」

と類似し た「エコ システム」 や「生物 多様性」 の概念, さらに 「林業」 や「レク リエーショ ン」といっ た記述が 加わり, 森林と人 との共生 の様子が 
表現されているもの とに分かれる。美し い風景のモデルとし て「文化景観」を描 くドイッの回答者と 「自然景観」を描く 日本の回答者との対 比は興味深い。

( 3 ) 「森林イメー ジ」と森林との関わ り方の対応関係

「森林イメージ」の特徵は森林との関わり方の個人属性から説 明できるのであろうか。ここでは両国の「森林イメージ」の特徵 を個人属性と対応させながら整理し考察を深めたい（表一 4, 5 )。

ドイツの回答者でとくに多く見られた「対象・中景」タイプは 林内景観を客観的に描写しており, 日本の回答者の「対象・近景」 タイプと「対象・中景」タイプに類似点が見られた。しかし, ド イツの回答者では, 最も知識が多く, 森林との関わりが相対的に 弱いグループが含まれるのに対して, 日本の回答者では「対象・ 近景」タイプに, 最も知識が多く, 現在まで引き続き森林体験が 多いグループが, 逆に「対象・中景」タイプには, 最も知識が少 なく, 森林との関わりも弱いグループが含まれた。また，同様に 森林との関わりが弱いグループが含まれる, 日本の回答者の「対 象・俯瞰景」「文化景観・俯瞰景」タイプでは，「森林イメージ」 が非日常的な体験の記憶と結びついて想起されている共通の傾向 があり, ドイッの回答者の「森林イメージ」には該当するタイプ が見られない。日本の回答者のみに見られた「自然景観・俯瞰景」 タイプには, 幼少期の環境, 遊び場として森林が存在した, 森林 との関わりが強いグループが含まれ，美しい風景のモデルとして の自然風景や概念的な生態系が表現されており，それぞれドイッ の回答者の「文化景観・俯瞰景」「対象・俯瞰景」タイプに類似 点が見られた。しかし, ドイツの回答者では「文化景観・俯瞰景」 タイプに, 最も知識が少なく, 森林との関わりも相対的に弱いグ ループが, 逆に「対象・俯瞰景」タイプには, 幼少期に森林で遊 び，現在まで引き続き森林体験が多いグループが含まれた。日独 の回答者で, 遊歩道や身近な森林を「森林イメージ」として想起 した両国の「文化景観・中景」タイプでは, ともに幼少期に森林 で遊んだ，森林との関わりが比較的強いグループが含まれた。

\section{5.まとめ}

日独の大学生を対象に, 景観としての森林イメージを, 描画実 験と森林との関わり方に関する質問紙を組み合わせて調查した。 その結果, ドイツの回答者は幼少期の環境や遊び場, 森林体験頻 度の点から日本の回答者に比べて森林との関わり方が強く, 森林 に関する知識も多いと言うことができた。しかし「森林イメージ」 はそのほとんどがレクリエーション空間, 概念的な風景モデルや 生態系といったステレオタイプとして想起されており，一部での み, 居住地の周辺空間としての「森林イメージ」が想起されてい た。一方で, 日本の回答者における「森林イメージ」は個人レベ ルで実に多様で, 森林との関わり方の強さに応じて, 風景や森林 の描写から森林体験そのものの描写へと変化する傾向があり, 比 較的森林との関わりが強いグループの「森林イメージ」の中には ドイッの回答者のものと類似する傾向も見られた。しかし，その 表現タイプは異なり, 詳細な森林描写では視点が接近した近景が 描かれたり, 美しい風景モデルや生態系の概念として, 人の手が 加わらない自然景観が描かれたりするなどの特徵が見られた。全 体を通してみると，ドイツの「森林イメージ」が純粋に「空間」
表 - 5 「森林イメージ」タイプごとの

幼少期の環境, 幼少期の遊び

\begin{tabular}{|c|c|c|c|c|c|c|c|c|c|c|}
\hline & \multicolumn{6}{|c|}{ 日本の回答者 } & \multicolumn{4}{|c|}{ ドイツの回答者 } \\
\hline & weill & pop & झః: & $\ddot{4}$ & peps & $\because \%$ & QPS & ฌओ & pepp & $\therefore$ \\
\hline & 娰,近 & & & 自,钵 & 文,中 & 文,筙 & 奶,中 & 对,倠 & 文,中 & 文解 \\
\hline \multicolumn{11}{|l|}{ 幼少期の㻴境 } \\
\hline 森 & 57 & 15 & 29 & 67 & 56 & 20 & 84 & 100 & 100 & 80 \\
\hline 農地 & 29 & 23 & 43 & 56 & 44 & 60 & 89 & 80 & 100 & 90 \\
\hline 草原 & 14 & 23 & 14 & 11 & 22 & 20 & 84 & 80 & 83 & 70 \\
\hline 公園 & 86 & 100 & 86 & 78 & 89 & 100 & 16 & 20 & - & 10 \\
\hline 放畗地 & 29 & 8 & 29 & 22 & 33 & 30 & 11 & 20 & - & 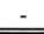 \\
\hline \multicolumn{11}{|l|}{ 幼少期の遊ひ場 } \\
\hline 森 & - & - & - & 33 & 11 & - & 32 & 60 & 67 & 20 \\
\hline 農地 & - & - & - & 11 & 11 & - & 16 & - & - & 20 \\
\hline 草原 & 14 & - & 14 & - & 11 & - & 26 & 20 & 50 & 20 \\
\hline 川, 池 & - & 8 & 29 & 22 & - & - & 16 & - & 17 & 20 \\
\hline 庭 & - & - & - & - & - & - & 47 & 60 & 17 & 20 \\
\hline 公園 & 57 & 62 & 57 & 56 & 56 & 60 & 11 & 20 & - & 30 \\
\hline 学校 & 14 & 15 & 14 & 11 & 33 & 20 & - & - & - & - \\
\hline 道、駐車場 & 29 & 15 & 14 & 11 & - & 20 & 26 & 20 & 17 & 20 \\
\hline その他外 & 29 & 15 & - & 22 & 22 & 30 & 37 & 20 & 17 & 40 \\
\hline 家| & 14 & 23 & - & - & - & 10 & - & 20 & - & - \\
\hline
\end{tabular}

としての森林の描写であるのに対し, 日本のそれは, 個人的な体 験の記憶と結びついた, ある時間の断片での「場所」としての森 林の描写となっている傾向があった。

今後の課題としては, 個人の森林イメージの表現形態の決定要 因に，量的に把握した森林之の関わり方の個人属性を対応させる には限界があるため，むしろ森林体験の質やさらにはそれを規定 する地理的要因や社会的要因に注目する必要があると言える。例 えば, 森林分布や都市と農村の関係に関しても, 日独では大きな 違いがあるし, ドイツの森は歩行者に開放され, 誰もが自由に散 策する事ができる。そのため, 道と結びついた文化景観としての 森林イメージが定着する土袞があり, 逆の言い方をすれば歩く事 が許されるのは林道に限られるため, 森林の景観体験は自ずと中 景に限定されるとも言える。また，標高が高い山が無ければ，遠 景としての森林や, ダイナミックな川の流れが森林イメージのモ チーフとなるのは難しくなるだろう。このように考えると, 日本 の森林イメージの多様さは, 決して森林との関わりの希薄さのみ に由来するものではないかもしれない。視点が風景の中を自由に 動き回る山水画と, 視点によって定められたパースペクティブの 中に景観が位置づけられる西洋の風景画に見られるような, 美し いとされる風景の型にこそ，景観の捉え方を説明する鍵が隠され ているかもしれず，さらなる研究が必要である。

\section{引用・参考文献}

1) 上田裕文 (2002)：森林のイメージに与える個人背景と既成 イメージの影響：ランドスケープ研究 65(5), 685-688

2 ) 四手井綱英ほか（1981）：森林環境に対する住民意識の国際 比較に関する研究：トヨ夕財団助成研究報告書

3 ) 比屋根哲 (2002)：ドイツと日本における森林利用者の林業 間の相違：日本林学会誌 84(2), 120-124

4 ) 北村昌美 (1995)：森林と日本人：小学館, 393-407

5 ) Annete Braun (2000) : Wahrnehmung von Wald und $\mathrm{Na}$ tur : Leske+Budrich, 214-216

6 ) Klaus Schriewer (1998): Die Wahrnehmung des Waldes im Wandel : Zeitschrift fuer Volkskunde 94, 4-17

7 ) Albrecht Lehman (2000): Der Wald Eindeutscher Myth os? : Reimer, 27-36

8 ) 大越美香 (2003)：子供の森林イメージと森林体験学習に関 する研究：農村計画学会誌 5, 259-264

9 ) 四手井綱英ほか（1981）：前掲書，105 